\title{
Natura 2000 fenntartási tervek részvételi folyamatainak értékelése
}

\author{
Kovács Eszter ${ }^{1,2}$, Kiss Gabriella ${ }^{3}$, Kelemen Eszter ${ }^{1,2}$, Fabók \\ Veronika $^{4,2}$, Kalóczkai Ágnes ${ }^{5,4,2}$, Mihók Barbara ${ }^{5,6}$, Pataki György ${ }^{3,2}$, \\ Balázs Bálint ${ }^{1,2}$, Bela Györgyi ${ }^{1,2}$, Megyesi Boldizsár ${ }^{7}$ és Margóczi \\ Katalin $^{8,6}$ \\ ${ }^{1}$ Szent István Egyetem, Természetvédelmi és Tájgazdálkodási Intézet, \\ 2100 Gödöllö, Páter Károly u. 1. \\ ${ }^{2}$ Environmental Social Science Research Group (ESSRG), \\ 1024 Budapest, Rómer Flóris u. 38. \\ ${ }^{3}$ Budapesti Corvinus Egyetem, 1093 Budapest, Fövám tér 8. \\ ${ }^{4}$ Szent István Egyetem, Környezettudományi Doktori Iskola \\ 2100 Gödöllö, Páter Károly u. 1. \\ ${ }^{5}$ MTA Ökológiai Kutatóközpont, Ökológiai és Botanikai Kutatóintézet \\ 2163, Vácrátót, Alkotmány u. 2-4 \\ ${ }^{6}$ Akciókutatók a Fenntarthatóságért Egyesület (AKUT), 6726 Szeged, Fürj u. 49. \\ ${ }^{7}$ MTA Társadalomtudományi Kutatóközpont, Szociológiai Intézet, \\ 1014 Budapest Országház u. 30. \\ ${ }^{8}$ Szegedi Tudományegyetem, Ökológia Tanszék, 6726 Szeged, Középfasor 52. \\ e-mail: kovacs.eszter@mkk.szie.hu
}

\begin{abstract}
Összefoglaló: A társadalmi részvétel intézményesülésének még csak csírái találhatók meg hazánkban, ennek ellenére az érintettek bevonása a Natura 2000 területek fenntartási terveinek készítésébe már gyakorlattá vált. Értékelésük hasznos lehet a tervek készítői, a részvételi folyamatok irányítói és a természetvédelmi döntéshozók számára is. Ebben a cikkben a nemzetközi szakirodalomban alkalmazott értékelési kritériumokra építve a részvételi fenntartási tervezéshez kiválasztott és adaptált 12 szempont alapján értékelünk 23 természetvédelmi részvételi tervezési folyamatot, melyek 2007 és 2016 között valósultak meg. Vizsgálataink azt mutatják, hogy az értékelt folyamatok csak részben felelnek meg az elvárt kritériumoknak. illetve a fenntartási tervek természetvédelmi hatásainak megítéléséhez nem is rendelkezünk megfelelő információval. Az elemzésben megjelenő tervezési folyamatok erőssége a felkészült, társadalomtudományos hátterü és független részvételi csapat. Emellett azt is megállapíthatjuk, hogy a fenntartási tervezés és a kapcsolódó részvételi folyamatok sikerességéhez kiemelten fontos a támogató szakpolitikai háttér is.
\end{abstract}

Kulcsszavak: részvételi tervezés, Natura 2000 hálózat, fenntartási tervek 


\section{Bevezetés}

Az érintettek természetvédelmi döntések meghozatalába való bevonásának fontosságát nemzetközi szinten már számos írás hangsúlyozza (ld. pl. Bagnoli et al. 2008, Reed 2008). A részvétel előnyeként tartják számon, hogy az érintett csoportok megvalósítás iránti elkötelezettsége nő, megindulhat egy kölcsönös tanulási folyamat a résztvevők körében, a konfliktusok időben felszínre kerülhetnek vagy megelőzhetőek, és a hosszú távú együttműködés alapjait is le lehet fektetni annak érdekében, hogy a felek egymást már ne ellenfélként kezeljék (Reed 2008, Evely et al. 2011, Young et al. 2013). A kedvező társadalmi hatások mellett egyes szerzők a bevonás pozitív természetvédelmi hatását is kiemelik, ugyanis amenynyiben az érintettek elfogadják a természetvédelmi célokat, esetleg aktívan részt is vesznek azok kialakításában és megvalósításában, akkor elkötelezettségük növelheti a természetvédelmi munka hatékonyságát és hatásosságát is (Young et al. 2013). Más kutatók a demokratikus elvekre hivatkozva hangsúlyozzák a részvétel fontosságát, $\mathrm{s}$ arra irányítják rá a figyelmet, hogy akit a döntés érint, annak joga van beleszólni az adott döntés meghozatalába, illetve a bevonás növeli a döntések legitimációját (Kiss 2012). Több kutató figyelmeztet azonban arra, hogy ha a részvételi folyamat nem megfelelően tervezett és kivitelezett, vagy sok akadályozó körülmény merül fel, akkor a társadalmi részvétel negatív következményekkel is járhat. Az érintettek bizalma ugyanis meginoghat a bevonási folyamatban, s egy következő, hasonló kezdeményezésben nem akarnak majd aktívan részt venni. Más esetekben a konfliktusok elmélyülhetnek ahelyett, hogy a feloldásukhoz közelítenénk (Rauschmayer et al. 2009, Young et al. 2013, Díez et al. 2015). A társadalmi részvétel és a természetvédelem kapcsolatát részletesen tárgyalja Mihók et al. (2016) ebben a kötetben.

A Natura 2000 területek fenntartási terveinek elkészítése jó alkalmat ad az érintett csoportok bevonására és a részvétel növelésére a természetvédelemben. A tervek összeállítása az élőhelyvédelmi irányelv és a vonatkozó magyar jogszabály (275/2004. (X. 8.) Korm. rendelet, a továbbiakban Natura rendelet) alapján sem kötelező, de az uniós elvárásokkal összhangban, a megőrzési intézkedések meghatározásának egyik eszközeként a természetvédelemért felelös minisztérium (jelenleg Földművelésügyi Minisztérium) ösztönzi ezek elkészítését. A fenntartási terveket független szakemberek is elkészíthetik, de minden esetben a természetvédelemért felelös minisztérium hagyja azt jóvá, és a tervezésbe be kell vonni az érintett nemzeti park igazgatóságot. Amennyiben készül terv, akkor az érintett csoportokkal való konzultáció kötelező, de annak módjára nincs részletes előírás (Natura rendelet, fenntartási tervek készítéséhez összeállított útmutató (Vidékfejlesztési Minisztérium 2013)). Az Európai Mezőgazdasági Vidékfejlesztési Alap 
(EMVA) támogatásával készülő tervekhez kiadott rendeletben már egy részletesebb elvárás szerepel az alkalmazandó kommunikációs csatornákra vonatkozóan (43/2012. (V. 3.) FM rendelet, a továbbiakban FM rendelet).

A részvétellel foglalkozó szakirodalom megkülönbözteti az állampolgárok részvételével zajló folyamatokat (public participation) a területhez vagy témakörhöz közvetlenül kapcsolódó érintett vagy érdekcsoportok bevonásával zajló folyamatoktól (stakeholder involvement) (Pellizzoni 2003, Hansen et al. 2016). Mivel a fenntartási tervek készítésénél a jogszabály nevesített érintett csoportokkal írja elő az egyeztetési kötelezettséget, ezért mi is az érintett csoportok bevonásával zajló részvételi folyamatként tekintünk a tervezésre.

A jelen cikkben 2007 és 2016 között végzett, Natura 2000 fenntartási tervek tervezésére irányuló részvételi folyamatok tapasztalatait foglaljuk össze, a szakirodalomból vett szempontok alapján történő kvalitatív értékeléssel. Az elemzésre kiválasztott részvételi folyamatok tervezését és kivitelezését jelen szerzői csapat tagjai végezték. Célunk annak bemutatása, hogy mennyire voltak sikeresek ezek a folyamatok, s mivel lehet segíteni továbbfejlesztésüket a jövőben.

\section{Módszerek}

Az értékelt részvételi folyamatok néhány jellemzőjének összefoglalása

A vizsgált részvételi folyamatok közös jellemzője, hogy mindegyik Natura 2000 területek fenntartási tervének elkészítésére irányult. A jelen cikkben értékelt öszszes részvételi folyamatot a korábban a Szent István Egyetemen müködő Környezeti Társadalomkutatók (Environmental Social Science Research Group ESSRG) tagjai hajtották végre, emellett az egyik projektben együttmüködtek egy társadalmi szervezettel (Akciókutatók a Fenntarthatóságért Egyesület - AKUT) is. A tervezési folyamatok három különböző projektben valósultak meg, amelyekben a részvételi tervezés eltérő volt felépítésében, finanszírozási forrásában, szervezeti formájában és a vizsgált folyamatok számában. A három projekt főbb jellemzőit mutatja be az 1. táblázat.

A részvételi tervezés módszertanát az első projektben dolgozta ki az ESSRG kutatócsoportja, s ezt alkalmazta, illetve fejlesztette tovább a későbbi projektekben. A konkrét terepi munkát minden esetben megelőzte egy előzetes adatgyüjtő háttérmunka (desk research), amellyel az adott terület természeti, társadalmi-gazdasági jellemzőit gyüjtöttük össze szakirodalmi és egyéb források (pl. statisztikai adatok) felhasználásával. Ezt követően félig strukturált interjúkat készítettünk az érintett csoportok körében (Patton 2002), amelyek célja egyrészt az érintettek megismertetése volt a tervezési folyamattal, másrészt a természetvédelemmel, a 
1. táblázat. A vizsgált fenntartási tervezési folyamatok jellemzői.

\begin{tabular}{|c|c|c|c|}
\hline & 1. projekt & 2. projekt & 3. projekt \\
\hline Időtartam & 2007-2009 & $2012-2013$ & $2013-2016$ \\
\hline $\begin{array}{l}\text { Finanszírozási } \\
\text { forrás }\end{array}$ & Átmeneti Támogatás & LIFE+ & $\begin{array}{l}\text { Svájci-Magyar } \\
\text { Együttmüködési } \\
\text { Program }\end{array}$ \\
\hline Konzorciumvezető & VÁTI Non Profit Kft. & $\begin{array}{l}\text { Magyar Madártani } \\
\text { és Természetvédelmi } \\
\text { Egyesület (MME) }\end{array}$ & $\begin{array}{l}\text { Magyar Madártani } \\
\text { és Természetvédelmi } \\
\text { Egyesület (MME) }\end{array}$ \\
\hline $\begin{array}{l}\text { Részvételi folya- } \\
\text { matok (területek) } \\
\text { száma }\end{array}$ & $\begin{array}{l}20 \text { folyamat ( } 20 \\
\text { terület) }\end{array}$ & 1 folyamat ( 1 terület) & 2 folyamat (12 terület) \\
\hline $\begin{array}{l}\text { A fenntartási terv } \\
\text { elfogadásának } \\
\text { időpontja }\end{array}$ & 2009 & 2015 & $\begin{array}{l}\text { a cikk írásakor még } \\
\text { nem volt benyújtva }\end{array}$ \\
\hline $\begin{array}{l}\text { A folyamatban } \\
\text { lefolytatott interjúk } \\
\text { (utóinterjúk) száma }\end{array}$ & 285 & $21(4)$ & 84 \\
\hline $\begin{array}{l}\text { A folyamat során } \\
\text { szervezett fórumok } \\
\text { száma }\end{array}$ & 16 fórum & 2 fórum & 4 fórum \\
\hline
\end{tabular}

Natura 2000 hálózattal és a lehetséges intézkedésekkel kapcsolatos véleményük, érdekeik feltárása (az interjúk számát lásd az 1. táblázatban). Egyes interjúkat terepbejárással is összekötöttünk. Az interjúk 40-90 percig tartottak, átlagos időtartamuk egy óra volt. Rögzítésük jegyzeteléssel történt, néhány esetben készült csak külön hangfelvétel az interjúalany előzetes beleegyezését követően. Az interjúzás és az elözetes adatgyüjtés eredményeit felhasználva érintett elemzést készítettünk, amelyben feltártuk a főbb érintett csoportok érdekeit, viszonyulását a tervezési folyamathoz, $\mathrm{s}$ rámutattunk a tervezés során várható problémákra és konfliktusos helyzetekre. Ez inputként szolgált a tervekhez, s egyúttal a fórumok előkészítését is segítette. Ezt követően négy terület kivételével, ahol a kevés számú érintett nem indokolta, a tervezési területekhez illeszkedve egyeztető fórumot tartottunk a terv első változatának megbeszélésére (a fórumok és résztvevőinek számát lásd az 1. táblázatban). A fórumokról hangfelvételek alapján jegyzőkönyvek készültek. Emellett az érintettek számára írásbeli véleményezési lehetőséget is biztosítottunk a terv egyeztetési változataira. Mindegyik projektben az érintetteknek elektronikus vagy postai úton küldtük ki az első tervváltozatot, amely a projekt hivatalos honlapjára szintén felkerült, a későbbi változatokkal együtt. Az első projektben a honlap egy szélesebb, ismeretterjesztő funkciót is ellátott, amelyen a terve- 
ken kívül más szakmai anyagok is megjelentek, s egy blog is müködött. Ebben a projektben ötletbörzét is tartottunk minden illetékes nemzeti park igazgatóság munkatársaival a tervben foglalt kezelési javaslatok megvalósítását segítő egyéb feltételek (pl. szabályozási környezet megváltoztatása, nem pénzügyi ösztönzők) feltárására. A második projektben utóinterjúzást is végeztünk az érintett csoportok körében és a tervezői csapattal a részvételi folyamat eredményességének vizsgálata céljából, a harmadik projektben pedig egy rövid kérdéssor megválaszolására kértük fel a tervezőket.

\section{Az értékelés módszertana}

A részvételi tervezési folyamatok értékelését azért tartjuk fontosnak, hogy megvizsgáljuk, a részvétel folyamata megfelelően zajlott-e, a folyamat eredményének hatásai előnyösek voltak-e a társadalomra és a természetre nézve. A korábbiakban már bemutattuk, miért is lehet lényeges és szükséges az érintettek bevonása a természetvédelmi tervek készítésébe, a folyamatok értékelésekor pedig azt vizsgáljuk, hogy az említett tervek készítésekor ezek az előnyök valóban jelentkeztek-e.

A részvételi folyamatok értékelése kellő körültekintést igényel, hiszen a folyamatok, a tervezés által érintett területek, a résztvevők is nagyon különbözőek lehetnek. Egy olyan egységes értékelési kritériumrendszerre van tehát szükség az értékelés során, amelyben a kritériumok egyértelmủek és jól definiáltak, így biztosítva különböző folyamatok esetén is az összehasonlítható és megbízható értékelést (Rowe \& Frewer 2000). Egy ilyen értékelési rendszer azt is megmutatja, hogyan javítható az egyes folyamatok minősége.

A részvételi folyamatok értékelésére a részvételi szakirodalomban többféle megközelítés létezik (Reed 2008, Kiss 2012). A Natura 2000 területek részvételi tervezésének értékelésében is alkalmazásra kerültek már különböző értékelési módszerek (lásd pl. Young et al. 2013). Mindezen szakirodalmi előzmények (Rowe \& Frewer 2000, Reed 2008, Young et al. 2013) alapján és a hazai részvételi folyamatok jellemzőit figyelembe véve építettük fel az értékelési kritériumrendszert. A szempontrendszer 12 értékelési kritériumot tartalmaz, melyek közül nyolc szempont magára a részvételi tervezési folyamatra, három a folyamat társadalmi hatásaira és egy a természetvédelmi hatásokra vonatkozik (ld. 2. táblázat).

A kiválasztott szempontok alapján elemeztük a rendelkezésre álló projektdokumentumokat (érintett elemzések, fórumjegyzőkönyvek, fenntartási tervek). Ezt kiegészítettük egy elektronikus levélváltással az első projektben érintett nemzeti park igazgatósági kollégákkal, amelyben az akkor elkészült tervek monitorozásával, felhasználásával kapcsolatos kérdéseket tettünk fel.

Esetünkben előnye és hátránya is van annak, hogy általunk tervezett és kivitelezett részvételi folyamatokat vizsgáltunk. Előnye, hogy részletesen ismerjük 
2. táblázat. A részvételi folyamatok értékelésének kritériumai és eredményei (0: nem teljesült, 1:részben teljesült, 2:teljesült)

\begin{tabular}{l} 
Az elemzési kritériumok \\
\hline Folyamat \\
1. a főbb érintett csopor- \\
tok részvétele \\
2. a főbb érintett csopor- \\
tok korai bevonása \\
3. világos célkitűzések \\
4. a döntési helyzethez \\
illeszkedő részvételi \\
módszertan alkalmazása \\
5. felkészült részvételi \\
csapat
\end{tabular}

\section{6. független részvételi csapat}

7. megfelelő erőforrások

8. támogató szakpolitikai háttér

\section{Társadalmi hatás}

9. párbeszéd a tervezők és érintett csoportok között

10. sikeres konfliktuskezelés

11. az érintettek javaslatainak beépülése a tervbe

\section{Természetvédelmi hatás}

12. a tervek megvalósulása
Minden érintett csoport részt vesz a tervezési folyamatban.

Az érintetteket a tervezésnek abban a fázisában kérdezik, amikor számukra valódi alternatívák állnak rendelkezésre.

A tervezési folyamat és a terv célja jól definiált és világos a résztvevők számára.

Eredmények

A különböző részvételi módszerek közül a területhez és a tervezéshez leginkább illeszkedő eszközök kerülnek alkalmazásra.

A részvételi folyamatot tervező és lebonyolító csapat a részvételi módszertan megfelelő ismeretével és a módszerek természetvédelmi projektekben való alkalmazása tekintetében többéves tapasztalattal rendelkezik.

A részvételi folyamatot tervező és lebonyolító csapat független a finanszírozótól és a döntéshozótól, valamint az érintettektől is.

Megfelelő pénzügyi forrás és idő áll rendelkezésre a folyamat lebonyolításához.

A szabályozás és az ösztönző rendszer kellő módon segíti a tervezést és a részvételt.

Kölcsönös és kétirányú kommunikáció van a tervezők és az érintettek között.

A folyamat során keletkező konfliktusokat sikerül feloldani, a már meglévő konfliktusok nem mélyülnek el.

A részvételi folyamat során az érintettek által tett javaslatok megjelennek a végső tervben.

A tervben kitüzött hosszú távú természetvédelmi nincs elérhecélok megvalósulnak. 
a folyamatokat, s személyes tapasztalatunk alapján megalapozottabb az értékelésünk. Hátránya viszont, hogy elfogultak lehetünk egyes szempontok esetében. Az ebből adódó kockázatokat (validitási csapdákat) többféle módon igyekeztünk elkerülni. Egyrészt a szempontok kiválasztásában egy külső, független (egyik tervezési folyamatban sem közremüködő), a részvételi folyamatok értékelésében jártas szakértő segítségét kértük. Másrészt a szakirodalomban már korábban is alkalmazott módszert használtunk. Harmadrészt az értékelésnél az objektivitásra törekedtünk, s összegző megállapításainkat minden szempont esetében az elemzett dokumentumokból vett tényekkel támasztottuk alá. Emellett az értékelést többen is végezték, így pontosítva annak tartalmát. Az értékelési folyamat során pedig folyamatosan reflektáltunk személyes érintettségünkre.

\section{Eredmények}

A 2. táblázatban bemutatjuk és röviden magyarázzuk az alkalmazott kritériumokat. valamint összegezzük a kapott eredményeket is. Ezt követően részletesen is kifejtjük az értékelés eredményeit, utalva a kritérium-rendszer megfelelő pontjaira.

\section{A folyamat értékelése (1-8. kritérium)}

1. A föbb érintett csoportok részvételére vonatkozó kritériumunk csak részben teljesült. Sokféle részvételi és kommunikációs eszközt alkalmaztunk (interjú, tervek postai és elektronikus úton való kiküldése véleményezésre, honlap, fórum), amellyel az érintettek széles körét el tudtuk érni a területek nagy részén még úgy is, hogy a földhasználókat illetően nem rendelkeztünk földhivatali nyilvántartási adatokkal. A második projektben, a jászsági fenntartási terv készítése során, viszont problémát jelentett az adathiány, itt a gazdálkodókat nem tudtuk a szükséges számban elérni, még a falugazdászok felkeresésével sem. A legtöbb területen, ahol nagyobb számú érintett volt, fórumot is tartottunk. A fórumok többségénél a legfontosabb érintett csoportok képviselete megvalósult. Az első projektben néhány területet érintően nem sikerült minden érintett csoportot mobilizálni a fórumokra, illetve a harmadik projektben a kiskunsági tervezési területen nem képviseltette magát minden fontos csoport, nagyszámú telefonos és írásbeli megkeresés ellenére sem. A kiskunsági területen a tervezési folyamat elhúzódása miatt a fórumok már belenyúltak a tavaszi munkálatok idejébe, ami csökkentette a fórumok sikerességét. Emellett a tervezési folyamat alatt folyt az érintett nemzeti park igazgatóság vagyonkezelésében lévő területeken a haszonbérleti szerződések megkötése a következő 10 évre, s a bérlők köre részben megváltozott az interjúzás 
és a fórum szervezése között, ami a részvétel eredményességét szintén csökkentette. Ebben a projektben az érintettek körét befolyásoló tényezőként jelentkeztek az önkormányzati választások és a falugazdász hálózat intézményi hátterében történt változások is.

2. Az érintettek korai bevonását a szakirodalom azért tartja fontosnak, hogy az érintetteknek legyen lehetőségük már a választási alternatívák kialakításában is részt venni az őket érintő döntési helyzetekben, értsék azokat, s ne egy kész döntési helyzet elé állítsák őket, melyet csak utólag van lehetőségük véleményezni (Rowe \& Frewer 2000). A fenntartási tervek készítése a Natura 2000 területek kijelölése után indult. A kijelölésnek az Európai Unióhoz való csatlakozásig (2004) meg kellett történnie, az élőhelyvédelmi irányelvben meghatározott szakmai kritériumrendszer alapján. A kijelölési folyamat gyorsan zajlott, és akkor sem idő, sem kapacitás nem volt arra, hogy a földhasználókat bevonják a folyamatba, vagy személyesen felvegyék velük a kapcsolatot a kijelölés kapcsán. A fenntartási tervek elkészitésébe már minden érintettnek volt lehetősége beleszólni, hiszen az interjúk során elmondhatták előzetes álláspontjukat, majd a terv egyes változatait véleményezhették, és az elöírásokat megvitathatták a fórumokon. Ezzel a lehetőséggel azonban a kijelölést elfogadó gazdálkodók és földhasználók tudtak csak igazán élni. Azok a földhasználók, akik nem értettek egyet a kijelöléssel, a fenntartási terv kialakítása kapcsán sem láttak elfogadható alternatívát, mert a kijelölésen változtatni nem tudtak. Emiatt mondhatjuk, hogy ez a kritérium csak részben teljesült.

3. Elemzésünk alapján a fenntartási tervek készítése során a világos célkitüzések kritérium szintén csak részben teljesült. A tervek összeállításának alapvető célja, vagyis a Natura 2000 területek jelölő fajainak és élőhelyeinek természetvédelmi állapotát megőrző intézkedések meghatározása, világos célkitüzés. A fenntartási tervek, a jogszabályban rögzített előírásokon túl, kötelező földhasználati szabályokat nem tartalmaznak, ezek alkalmazása a támogatási környezettöl függ. A tervek alapvetően olyan stratégiai dokumentumok, amelyek a megőrzési célhoz rendelhető intézkedési, kezelési javaslatokat tartalmazzák. Ez, a többi, természetvédelmi elemeket tartalmazó tervtől való eltérés, a tervek kommunikációjánál problémákat okozott, s számos fórumon kaptunk kérdéseket ezzel kapcsolatban. A többi, természetvédelmi elemeket tartalmazó terv, amelyhez a fenntartási tervek kapcsolódhatnak (pl. kezelési terv, körzeti erdőterv), kötelező érvényü és pontosan meg van határozva a felülvizsgálatuk időpontja is. Mivel a földhasználók általában a kötelező érvényü tervekkel találkoznak, ezért nem teljesen volt értelmezhető számukra a fenntartási terv választható jellege. Azt is több esetben kifogásolták, hogy ha a terv a gazdálkodáshoz köthetően csak javaslatokat tartalmaz, akkor miért nincsenek a betartásához pénzügyi ösztönzők rendelve. Szin- 
tén problémát jelentett, hogy a fenntartási terv más tervekhez való viszonya nem volt egyértelmü egyes földhasználói csoportok számára. Ezt tapasztaltuk például a harmadik projektben, a Mátrához kapcsolódó Natura 2000 területekre készülő fenntartási tervek esetében. Itt, annak ellenére, hogy a tervek az egyéb jogszabályokban rögzítetteken túl kötelező földhasználati elöírást nem tartalmaznak, az állami erdőgazdálkodó aggályát fejezte ki arra vonatkozóan, hogy az intézkedéseket majd beépítik a kezelési tervbe vagy a körzeti erdőtervbe, $\mathrm{s}$ akkor betartásuk kötelezö lesz.

4. A döntési helyzethez illeszkedö módszertan alkalmazása az általunk tervezett és kivitelezett fenntartási tervezési folyamatokban szintén csak részben teljesült. Az első projektben kísérletezte ki a kutatócsoport a részvételi módszertant a 20 tervezési területen. Az érintettek körének és érintettségének feltárását a bevonás több lépcsős, egyéni és csoportos módszerei segítették, és az esetek nagy részében biztosították az érintettek lehetö legteljesebb részvételét a folyamatban. Az alkalmazott módszertan azonban nem kellően rugalmas a külső és belső váratlan helyzetek kezelésére, amit a harmadik projektben tapasztalhattunk meg. Ebben a projektben a folyamatok sikerességét a korábban említett külső tényezők (fórumok belenyúlása a tavaszi munkálatok idejébe és a földhasználói kör változása) is erősen befolyásolták. A harmadik projektben a tervek már nagyon összetettek voltak (madárvédelmi területekkel átfedő élőhelyvédelmi területekre egyszerre készültek), aminek a részleteit nehéz volt a fórumokon úgy átadni, hogy kellö részletezettségü is legyen, s emellett alkalmat adjon az érdemi párbeszédre. Kevés konkrét gazdálkodói észrevétel érkezett ebben a projektben, ami szintén azt mutatja, hogy a bevonási formákat érdemes továbbfejleszteni.

5. A felkészült részvételi csapat kritériuma teljesült, hiszen a kutatócsoport tagjai a fenntartási tervek készítésének idejében a részvételi módszerek (interjúzás, érintett elemzés, ötletbörze, fórum) tervezése, véghezvitele, dokumentálása, elemzése tekintetében megfelelő képzettséggel és azok természetvédelmi célú alkalmazásában több éves gyakorlattal rendelkeztek. Emellett a kutatócsoportunk a társadalmi részvétel iránt elkötelezett, a részvételi módszertan továbbfejlesztését és gyakorlatba való beépítését fontosnak tartja kutatásai során is. Ezt a hozzáállást alkalmaztuk a fenntartási tervezés folyamataiban is. A harmadik projektben a kutatócsapattal együttmüködő civil szervezet tagjait és az interjúzásban részt vevő egyetemi hallgatókat külön képzésben részesítettük. A kutatócsoportunk kutatási szinten foglalkozik a környezeti konfliktusok feltárásával és kezelésével. Az erre vonatkozó ismereteinket a fenntartási tervezéses folyamatokban is tudtunk hasznosítani.

6. A független részvételi csapat kritériuma szintén teljesült. A részvételi folyamatok végzőinek függetlensége azért fontos, mert egy független szervezet képvi- 
selőjeként könnyebben lehet az érintettek bizalmát megnyerni a folyamat iránt, feltárni a problémáikat, a konfliktusokat felszínre hozni és elörelépni a megoldásukban. Az érintettek így jobban tudják képviselni saját értékeiket és bíznak abban, hogy véleményük hatással lehet a tervekre. A kutatócsoport és a harmadik projektben vele együttmüködő civil szervezet is független volt a megbízótól és az érintett csoportoktól is.

7. A részvételi folyamatokra biztositott eröforrások, különösen a pénzügyi források és az idő, nagyban befolyásolják a folyamatok sikerességét. Az általunk vizsgált fenntartási tervezési folyamatoknál ez a szempont csak részben teljesült. A biztosított anyagi források megfelelőek voltak mindhárom projektben, ami lehetőséget adott az átgondolt és sok bevonási eszközt alkalmazó részvételi folyamatra. A rendelkezésre álló idő a második és harmadik projektben szintén megfelelő volt. Az első projektben azonban a két év szükösnek bizonyult, ugyanis 20 területen folyt párhuzamosan a tervezés, és ezzel összehangoltan a részvételi folyamatok tervezése és megvalósítása is.

8. A támogató szakpolitikai háttér szintén csak részben teljesült a vizsgált tervezési folyamatok esetében. A Natura rendeletben és a fenntartási tervek készítését segítő minisztériumi útmutatóban (Vidékfejlesztési Minisztérium 2013) az érintett csoportokkal való egyeztetés megjelenik követendő elvárásként, ami megteremti a részvételi tervezés lehetőségét. Mivel a tervek a jogszabályokban meghatározottakon túl csak önkéntesen vállalt kezelési javaslatokat tartalmaznak, további ösztönzők szükségesek ahhoz, hogy a földhasználók be is tartsák azokat. Az Európai Mezőgazdasági Vidékfejlesztési Alapból a gyep- és erdőterületekre biztosított Natura 2000 kompenzációs támogatás, illetve az agrár-környezetgazdálkodási és erdő-környezetvédelmi kifizetések a területek egy részén segíthetik a fenntartási tervekben foglalt célok megvalósítását, de ezek a támogatási formák országos szinten még nincsenek teljesen összehangolva a fenntartási tervezéssel, és ezért csak közvetetten tudnak érvényesülni. A Natura 2000 erdős területekre vonatkozó kompenzációs támogatás az első tervezési projekt idején még nem volt elérhető. A harmadik projektben már látszott a hatása, mert például egy, a Mátrában, a Natura 2000 hálózaton kívül eső területen müködő magán erdőgazdálkodó jelezte, hogy csatlakozna a hálózathoz. Az állami tulajdonú területek kezelői ezt a támogatási formát azonban nem vehetik igénybe, amit az ugyanezen a tervezési területen müködő állami erdőgazdálkodók problémaként is jeleztek.

\section{A társadalmi hatás értékelése (9-11. kritérium)}

9. Az érintett csoportok és a tervezök közötti párbeszéd, kölcsönös információcsere, eszmecsere, a részvételi folyamatok fontos társadalmi kimenete lehet. Ez a vizsgált folyamatoknál csak részben valósult meg. A párbeszédet segítheti a terve- 
zők nyitottsága az érintett csoportok véleménye iránt, a szakmai tartalom érthető módon történő átadása és a technikai nyelvezet helyett a közérthető fogalmazás. A fenntartási tervek részvételi folyamataiban együttmüködtünk a fenntartási tervek készítöivel. A fórumokon ők mutatták be a terveket, magyarázták el a tervezett intézkedéseket, és válaszoltak a felmerült kérdésekre, felvetésekre. Az első projektben még nem minden esetben valósult meg a fórumokon a kölcsönös információcsere, a tervezők sem mindig voltak felkészülve a nyitott, technikai kifejezésektől mentes kommunikációra, bár az ezzel kapcsolatos elvárásokról sokszor esett szó a projektmegbeszéléseken. A második és harmadik projektben a tervezői csapattal a fórumok előtt már személyesen is átbeszéltük a lehetséges problémákat, az elöadások felépítését, valamint külön felhívtuk a figyelmüket a közérthető nyelvezetre mind az előadás, mind az észrevételekre adott válaszok esetében. A második projektben két fórumot is tartottunk a tervezési területen, amely jó lehetőséget adott arra, hogy az érintett csoportok megismerjék egymás véleményét. Itt az utóinterjúk is azt mutatták, hogy megindult a kölcsönös tanulás a felek között. A harmadik projektben a tervek összetettsége miatt azonban a fórumokon hoszszabb előadásokra volt szükség, s kevesebb idő maradt a konkrét kezelési javaslatok részletes megvitatására. Ez az adottság korlátozta a gazdálkodók és a tervezők közötti lényegi párbeszéd lehetőségét.

10. A fenntartási tervek készítése kapcsán felszínre kerülhetnek konfliktusok, amelyek kezelése fontos a tervezés sikeressége szempontjából. Az általunk kivitelezett részvételi folyamatoknál csak részben tudtuk feloldani ezeket a konfliktusokat. Az első projektben (pl. a Dél-balatoni berkek esetében), és a harmadik projektben (pl. a mátrai tervezési területen) is felmerültek a Natura 2000 területek kijelölésével kapcsolatos konfliktusok. Ezek általában olyan területeknél jelentkeztek, ahol a természetvédelmi célokkal nem teljesen egyező fejlesztéseket képzeltek el a helyi tulajdonosok, területhasználók. A kijelölés miatt jelentkező konfliktusok kezelése a tervezői és részvételi csapat hatáskörén kívül esett, ezért ezek feloldásában előrelépni nem tudtuk. Ezen kívül megjelentek más konfliktusok is, részben a terület használatára vonatkozóan (pl. a második projektben, a Jászság területén a parlagi sas védelme kapcsán a mezőgazdálkodók, a természetvédők és a vadgazdálkodók között (ld. erről Fabók et al. 2015, Kovács et al. 2016)) vagy a harmadik projektben a mátrai tervezési területen az erdőgazdálkodást érintően (pl. holtfa, feltáró utak, szálalás témakörében), illetve a természetvédelmi kezelési javaslatokkal kapcsolatban több területen. Az interjúk és fórumok hozzájárultak a fontosabb konfliktusok, nézeteltérések feltárásához. A fórumok és tervezői egyeztetések pedig azt segítették, hogy a konfliktusok kezelésében elörelépés legyen, és a tervezők a konkrét természetvédelmi kezelési javaslatokat a gazdálkodói gya- 
korlathoz jobban közelítsék. S bár ez utóbbi típusú konfliktusok feloldásában volt elörelépés, teljes kezelésükre nem volt lehetőség egyik esetben sem.

11. A folyamat társadalmi sikerességét mutatja az is, hogy az érintett csoportoktól beérkezett javaslatok beépülnek-e a tervekbe. Ebben a tekintetben is részleges sikereket értünk csak el. Az első projektben a legtöbb terv esetében nem volt követhetö az észrevételek kezelése, vagy a beérkezett javaslatok egy része nem volt érdemleges, illetve azoknak csak egy részével értettek egyet a tervezők. A második projektben a jászsági területen sok gazdálkodói javaslatot figyelembe vettek a terv készítése során (pl. gyepterületeknél a hengerezés tiltása vagy kaszálásnál fütarló biztosítása kihúzásra került), s ez a második fórumjegyzőkönyvben követhető is. A harmadik projektben a cikk írásáig nem készültek még el a végleges tervek, de a tervezők tájékoztatása alapján a kiskunsági területekre vonatkozó tervekhez valószínüsíthetően lesz olyan táblázat, amely az észrevételek kezelésének mikéntjét bemutatja, a mátrai területekre készülő tervekhez azonban nem lesz ilyen.

A természetvédelmi hatás értékelése (12. kritérium)

12. Pozitív természetvédelmi hatás akkor jelentkezik, ha a tervekben foglalt kezelési javaslatokat megvalósítják, s a kitüzött hosszú távú természetvédelmi célok (a jelölő fajok és élőhelyek kedvező természeti állapotának biztosítása) megvalósulnak. Ez egy lényeges kritérium a szakmai eredményesség szempontjából, ezért alapvetően fontos e feltétel teljesülésére vonatkozó adatgyüjtés hosszú távon, $s$ az eredmények megismertetése az érintett csoportokkal. Az általunk vizsgált tervezési folyamatok esetében azonban nem tudunk a tervek teljesüléséröl és a természetvédelmi hatásokról beszámolni, ami fontos tanulság és továbbgondolást igényel. Az első projekt terveinél ugyanis a tervek teljesülését és hatásait nem követték nyomon, a második projektben csak 2015-ben fogadták el a tervet, így még túl rövid idő telt el a hatás vizsgálatához, a harmadik projektben pedig a cikk írásáig még nem készültek el a végleges tervek. A tervekben foglalt kezelési javaslatok megvalósulása és a természetvédelmi hatások nyomon követésének nevesítése azonban az újabb tervek esetében sincs beépítve a tervezésbe.

\section{Értékelés}

Az eredmények áttekintésével megállapíthatjuk, hogy a vizsgált részvételi tervezési folyamatokat csak részben voltak sikeresek. Ez egy közepes eredmény, amely azt mutatja, hogy vannak pozitív elemek, de számos értékelési kritérium esetében érdemes a tervezési folyamat továbbfejlesztésén gondolkodni. A legjobb eredményt a független és felkészült részvételi csapat kapta, legkevesebb információnk pedig a tervek végrehajtásáról volt az értékelés folyamán. 
Eredményeink azt mutatják, hogy a részvételnek számos hozzáadott értéke volt a tervezéshez. Az érintettek széles körü és több csatornán keresztül történő bevonása segítette, hogy a tervekkel kapcsolatos vélemények, javaslatok felszínre kerüljenek, s a tervezők munkáját jobban orientálják. A fórumok lehetőséget adtak a párbeszédre, a természetvédelmi és gazdálkodási érvek kölcsönös megismerésére, s számos tervezési területen hozzájárultak a kezelési javaslatokkal kapcsolatos egyes konfliktusok kezeléséhez is. Az szintén valószínűsíthetö, hogy az érintettek bevonása és a párbeszéd nemcsak a tervek, hanem általában a Natura 2000 hálózat és a természetvédelem elfogadottságában is hozott pozitív elmozdulást.

A vizsgált részvételi folyamatok nagy erősségének tartjuk, hogy azokat független, társadalomtudományos háttérrel rendelkező, részvételi módszerek alkalmazásában jártas, a társadalmi részvételt és környezeti konfliktusokat is kutató csoport tervezte és irányította. A társadalomtudományos hátteret és minőségi facilitációt a természetvédelmi témákkal foglalkozó részvételi szakirodalom is fontos szempontnak ítéli (Reed 2008). A természetvédelemben - nemzetközi és hazai szinten egyaránt - a természettudományos szakértői háttér a jellemző, de egyre több esetben (pl. területhasználati konfliktusoknál, földhasználókkal és szélesebb társadalmi rétegekkel való együttmúködések esetén) ez már nem elegendő a természetvédelmi munka sikerességéhez (Madden \& McQuinn 2014, O’Rourke 2014). A jelentkező problémák és a felismert lehetőségek hatására is megjelent az igény a társadalomtudományos hátterű szakértők és az általuk alkalmazott módszerek iránt. A hazai természetvédelemben a jelenlegi társadalomtudományos kapacitások ugyan korlátozottak, de képzéssel bővíthetők, mint ahogy ezt a harmadik projektben vizsgált tervezési folyamatoknál is láthattuk.

Az értékelt fenntartási tervezési folyamatok esetében azt tapasztaltuk, hogy bármennyire is jó a részvétel szakmai háttere, nagyon sok múlik azon, milyen a fenntartási tervek készítésének szakpolitikai megalapozása és a folyamatok szakpolitikai támogatottsága.

A Natura 2000 területek kijelölése az uniós tagállamokban természetvédelmi szakmai elvárások alapján történt, először szélesebb társadalmi egyeztetés és kompenzáció nélkül, amely konfliktusokat okozott számos országban (Hiedanpää 2002, Rauschmayer et al. 2009, Grodzińska-Jurczak \& Cent 2011). Magyarországon a fenntartási tervezés során, leggyakrabban a kijelöléshez közeli első projektben, de még a harmadik projektben is felszínre kerültek ilyen jellegü konfliktusok. Ezeket a konfliktusokat nem lehetett a tervezés keretei között kezelni, és föleg az első projektben, hátráltatták a részvételi tervezést. Érdemes tehát a szakmai döntéshozóknak a további fenntartási tervek készítésénél figyelmet fordítani ezekre a potenciális, kijelöléssel kapcsolatos konfliktusokra, valamint segíteni a tervezöket és a részvételi folyamat irányítóit a konfliktusok kezelésében. 
Számos uniós tagállamban a fenntartási tervek kötelező érvényüek (European Commission 2014). Mivel a magyarországi fenntartási tervek esetében a javasolt intézkedések (a jogszabályban meghatározott előírásokon kívül) önkéntesek, ezért fontos, hogy legyenek olyan ösztönzők, amelyek megvalósításukat segítik. Európai uniós szinten is hangsúlyozzák, hogy a Natura 2000 kompenzációs kifizetések, illetve az agrár-környezetgazdálkodási és erdő-környezetvédelmi támogatások nagyban segíthetik a Natura 2000 hálózat céljainak, s egyben a fenntartási tervek megvalósulását, valamint a potenciális konfliktusok csökkentését is (Kettunen et al. 2014ab). Ezeket a támogatási formákat azonban érdemes lenne jobban összehangolni a fenntartási tervek készítésével, hogy a tervekben foglalt előírásokra legalább részben épüljenek a kifizetések. Helyi szinten jó példa erre a második projektben, a jászsági területen javasolt és meg is valósult magas természeti értékü terület kijelölése és kapcsolódó agrár-környezetgazdálkodási kifizetések bevezetése (ld. Kovács et al. 2016).

Az uniós tagállamok egy részében a fenntartási tervek hatósági eljárásokban jogalapnak számítanak (European Commission 2014). A hazai fenntartási tervek esetében azonban nincs meghatározva, hogy azokat kik és mire használják majd, illetve hogyan kapcsolódnak a többi, természetvédelmi elöírásokat tartalmazó tervhez. Ez nehezíti a részvételi folyamatok során a kommunikációt, a fenntartási terv pontos célkitüzéseinek megfogalmazását és a konfliktusok kezelését is, ahogyan ez a vizsgált folyamatokban is történt. Érdemes lenne ezeket a kérdéseket szakpolitikai szinten is elemezni és kezelni.

A természetvédelmi célú részvétellel foglalkozó szakirodalom hangsúlyozza, hogy a társadalmi hatáson túl fontos a részvételi folyamatok természetvédelmi kimenete (Young et al. 2013). Ahogy korábban bemutattuk, a fenntartási tervek készítésénél nincs a kezelési és intézkedési javaslatok és a kitüzött természetvédelmi célok megvalósulására vonatkozó adatgyüjtés. Ha a tervezés természetvédelmi hatásáról így nem tudunk mit mondani, az a természetvédelmi szakpolitika és a részvételi folyamatok sikerességének megítélése szempontjából sem szerencsés. Érdemes lenne emiatt a tervezésbe beépíteni a tervek nyomon követésére vonatkozó elvárásokat is.

Az általunk értékelt fenntartási tervezési folyamatoknál azt is tapasztaltuk, hogy fontos a részvételi módszertan folyamatos továbbfejlesztése. Az első projektben kikísérletezett módszerek jó alapot nyújtanak a sikerességhez, de ahogy a tervek egyre összetettebbek, változik a szakpolitikai háttér, új módszerekre, rugalmasabb megoldásokra lehet szükség. Ez az adaptív menedzsment felé való elmozdulást is jelentheti (Allen et al. 2011). Progresszív lépés lehet (akár az adaptív menedzsment részeként is), ha az érintettek és a tervezők közösen alakítják ki a kezelési javaslatokat, s nem csak a terv első változatát követően van lehetőségük a vissza- 
jelzésre. A részvételiségnek egy magasabb szintjét lehetne ily módon megvalósítani (Arnstein 1969). Ez a folyamat azonban a jelenleginél nagyobb szakpolitikai támogatottságot, idö- és pénzügyi ráfordítást, valamint a tervezőktől is nagyobb rugalmasságot igényel.

Magyarországon, a közép-kelet-európai, volt szocialista országokhoz hasonlóan, a társadalmi részvétel nem tekint hosszú múltra vissza, $\mathrm{s}$ kevés tapasztalattal rendelkezünk e téren. Korábban a természetvédelemben sem voltak jellemzőek a részvételi folyamatok, az államigazgatási szabályok alapján hozott döntések voltak túlsúlyban, ahol a területhasználókkal kevés esetben történt személyes egyeztetés. Ez szintén a régió sajátossága (Niedziałkowski et al. 2014). A rendszerváltás óta azonban egyre több közép-kelet-európai országban indultak meg a természetvédelemben is a részvételi folyamatok (ld. pl. Lawrence 2008, Rodela \& Udovč 2008, Švajda 2008, Cent et al. 2014). Magyarországon is több természetvédelmi irányultságú részvételi folyamat zajlott már (ld. pl. Malatinszky et al. 2013, Mihók et al. 2014, Molnár et al. 2016, összefoglaló az esetekről jelen kötetben, Mihók et al. 2016)

A részvételi szakirodalom hangsúlyozza, hogy a társadalmi bevonás lehetőséget biztosít a közös tanulásra, amely egy szélesebb társadalmi tanulás része is lehet (Reed 2008, Reed et al. 2010). A fenntartási tervek készítése jó alkalmat adott arra, hogy elinduljon egy ilyen társadalmi tanulási folyamat, amelynek a területhasználókon kívül a tervezők, a részvételi folyamatok irányítói és a természetvédelmi szakpolitika különböző szintü képviselöi is részesei voltak. A közepes eredmény azt is mutatja, hogy a tanulási folyamat elkezdődött ugyan, de érdemes ezt tovább folytatnunk.

Végezetül három általános javaslatot fogalmazunk meg, amelyek elösegíthetik a fenntartási tervek részvételi tervezésének sikerességét a jövőben:

1. Fontosnak tartjuk, hogy a természetvédelmi célú részvételi folyamatok tervezésével és irányításával megbízott szakemberek ismerjék és alkalmazni tudják a részvételi módszereket. Ezek közül kiemelten fontosnak gondoljuk a fórumok megszervezéséhez és lebonyolításához kapcsolódó facilitátori képességek erősítését, a vitás ügyek rendezését segítő erôszakmentes kommunikáció alkalmazásának támogatását, valamint a tervezés megalapozó szakaszában használatos interjúk módszertanilag megfelelő kivitelezését.

2. Úgy gondoljuk, hogy a fenntartási tervek részvételi tervezésével kapcsolatos tapasztalatok kölcsönös megosztása a fenntartási tervek eddigi és leendő készítői között segítheti a buktatók korai felismerését és a tervezési folyamat rugalmas „helyszínre” szabását. Ehhez jó alapot adhat a cikkben megadott szempontrendszer, amely strukturáltan és a nemzetközi szakirodalomhoz illeszkedően teszi lehetővé a fejlesztési pontok azonosítását. A korábbi projektek során készült szak- 
mai módszertani útmutatók széles körben való terjesztése szintén hozzájárulhat a tudásmegosztáshoz.

3. Javasoljuk a fenntartási tervek szakpolitikai kereteinek pontosítását, amely a részvételi folyamatok hatékonyságát is növelheti. Ahogy azt már a korábbiakban részleteztünk, a más természetvédelmi elöírásokat tartalmazó tervekkel való nagyobb összhang megteremtése, az EMVA-ból nyújtott támogatásokhoz való szorosabb kapcsolódás, a felhasználási kör pontosítása és a tervek megvalósulásának nyomon követésére vonatkozó elöírások meghatározása jelenthet továbbfejlesztési irányokat.

Köszönetnyilvánitás - A fenntartási tervek vizsgált részvételi tervezési folyamatai az Átmeneti támogatás (2006/18/176.02.01), a LIFE+ (A parlagi sas védelme Magyarországon Helicon LIFE+ projekt, LIFE10NAT/HU/019) és a Svájci Együttmüködési Program (Fenntartható természetvédelem magyarországi Natura 2000 területeken c projekt, SH/4/8) finanszírozásával valósult meg. A szerzők köszönetet mondanak az Környezeti Társadalomkutatók csoportnak (ESSRG) a támogatásukért. A cikk megírásában Mihók Barbarát az MTA Lendület programja, a Szent István Egyetem kutatóit a Kutató Kari Kiválósági Támogatás - Research Centre of Excellence (11476-3/2016/FEKUT) is támogatta. Köszönjük a projektek résztvevőinek és a tervezőknek, hogy együttmüködtek velünk, és hálásak vagyunk interjúalanyainknak, a fórumokon résztvevőknek, az első projektben érintett nemzeti park igazgatósági kollégáknak, a 2. és 3. projekt tervezőinek, hogy megosztották velünk véleményüket. $\mathrm{S}$ végül köszönjük a bírálóknak a korábbi változathoz füzött értékes észrevételeket.

\section{Irodalomjegyzék}

Allen, C. R., Fontaine, J. J., Pope, K. L. \& Garmestani, A. S. (2011): Adaptive management for a turbulent future. - J. Environ. Manage. 92: 1339-1345. http://dx.doi.org/10.1016/j.jenv$\underline{\operatorname{man} .2010 .11 .019}$

Arnstein, A. (1969): A ladder of citizenship participation. - J. Am. I. Planners 26: 216-233. http:// dx.doi.org/10.1080/01944366908977225

Bagnoli, P., Goeschl, T. \& Kovács, E. (2008): People and Biodiversity Policies, Impacts, Issues and Strategies for Policy Action. - OECD Publishing, Paris. 249 p.

Cent, J., Grodzińska-Jurczak, M. \& Pietrzyk-Kaszyńska, A. (2014): Emerging multilevel environmental governance - A case of public participation in Poland. - J. Nat. Conserv. 22: 93-102. http://dx.doi.org/10.1016/j.jnc.2013.09.005

Díez, M. A., Etxano, I. \& Garmendia, E. (2015): Evaluating Participatory Processes in Conservation Policy and Governance: Lessons from a Natura 2000 pilot case study. - Environ. Pol. Governance 25: 125-138. http://dx.doi.org/10.1002/eet.1667

European Commission (2014): Establishing conservation measures for Natura 2000 Sites, A review of the provisions of Article 6.1 and their practical implementation in different Member States. European Comission, 40 p. 
Evely, A. C., Pinard, M., Reed, M. S. \& Fazey, I. (2011): High levels of participation in conservation projects enhance learning, Conserv. Lett. 4:116-126. http://dx.doi.org/10.1111/j.1755263X.2010.00152.x

Fabók, V., Kovács, E. \& Kalóczkai, Á. (2015): Érintettek percepcióinak feltárása egy védett ragadozómadarakkal kapcsolatos konfliktusban a Jászság SPA részvételi tervezési folyamata során. -Természetvédelmi Közlem. 21: 64-75.

Grodzińska-Jurczak, M. \& Cent, J. (2011): Enlargement of nature conservation areas - Problems with Natura 2000 implementation in Poland? - Environ Manage 47: 11-27. http://dx.doi. org/10.1007/s00267-010-9583-2

Hansen, H. P., von Essen, E. \& Sriskandarajah, N. (2016): Citizens, Values and Experts: Stakeholders: The Inveigling Factor of Participatory Democracy. - In: Hansen, H. P., Nielsen, B. S., Sriskandarajah, N. \& Gunnarsson, E. (szerk.): Commons, Sustainability, Democratization Action Research and the Basic Renewal of Society. Routledge, New York, pp. 113-138.

Hiedanpää, J. (2002): European-wide conservation versus local well-being: The reception of the Natura 2000 Reserve Network in Kavia, SW-Finland. - Landscape Urban Plann. 61: 113-123. http://dx.doi.org/10.1016/S0169-2046(02)00106-8

Kettunen, M., Green, S., McConville, A., Menadue, H., Newman, S., Poláková, J., Torkler, P. \& Underwood, E. (2014a): Financing Natura 2000 Guidance Handbook. Part II - Analysis of Natura 2000 management measures eligible for financing in 2014-2020 - a publication commissioned by the European Commission DG Environment, Publication Office of the European Union, Luxembourg, $148 \mathrm{p}$.

Kettunen, M., Torkler, P., Rayment, M. (2014b): Financing Natura 2000 Guidance Handbook. Part I - EU funding opportunities in 2014-2020 - a publication commissioned by the European Commission DG Environment, Publication Office of the European Union, Luxembourg, $84 \mathrm{p}$.

Kiss, G. (2012): Milyen a jó részvétel? Társadalmi részvételi folyamatok értékelése környezeti ügyekben. - Társadalomkutatás 30(4): 370-385. http://dx.doi.org/10.1556/Tarskut.30.2012.4.5

Kovács, E., Fabók, V., Kalóczkai, Á. \& Hansen, H. P. (2016): Towards understanding and resolving the conflict related to the Eastern Imperial Eagle (Aquila heliaca) conservation with participatory management planning. - Land Use Pol. 54: 158-168. http://dx.doi.org/10.1016/j.landusepol.2016.02.011

Lawrence, A. (2008): Experiences with participatory conservation in post-socialist Europe. - Int. J. Biodiversity Science and Management 4: 179-186.

Madden, F. \& McQuinn, B. (2014): Conservation's blind spot: The case for conflict transformation in wildlife conservation. - Biol. Conserv. 178: 97-106. http://dx.doi.org/10.1016/j.biocon.2014.07.015

Malatinszky, Á., Ádám, Sz., Saláta-Falusi, E. Saláta, D. \& Penksza, K. (2013): Planning management adapted to climate change effects in terrestrial wetlands and grasslands. - Int. J. Global Warming 5(3): 311-325. http://dx.doi.org/10.1007/s10584-012-0689-9

Mihók, B., Kiss, G., Kovács, E., Margóczi, K., Fabók, V., Kalóczkai , Á. (2016): Ki mondja meg, mi a fontos? - Részvétel és természetvédelem, Természetvédelmi Közlem. 22: 131-154.

Mihók, B., Pataki, Gy., Kovács, E., Bartha D., Csányi, S., Erős, T., Margóczi, K., Standovár T., Szemethy, L., Török, K., Török, P., Báldi, A. et al. (2014): A magyarországi természetvédelem legfontosabb 50 kutatási kérdése a következő 5 évben. - Természetvédelmi Közlem. 20: 1-23.

Molnár, Zs., Kis, J., Vadász, Cs., Papp, L., Sándor, I., Béres, S., Sinka, G. \& Varga, A. (2016): Common and conflicting objectives and practices of herders and conservation managers: the need for a conservation herder. - Ecosyst. Health Sustainability 2(4): Paper e01215. 16 p. (http://onlinelibrary.wiley.com/doi/10.1002/ehs2.1215/full, letöltés: 2016. április) http://dx.doi.org/10.1002/ ehs2.1215 
Niedziałkowski, K., Blicharska, M., Mikusinski, G. \& Jedrzejewska, B. (2014): Why is it difficult to enlarge a protected area? Ecosystem services perspective on the conflict around the extension of the Białowieza National Park in Poland. - Land Use Pol. 38: 314-329. http://dx.doi. org/10.1016/j.landusepol.2013.12.002

O'Rourke, E. (2014): The reintroduction of the white-tailed sea eagle to Ireland: People and wildlife. - Land Use Pol. 38: 129-137. http://dx.doi.org/10.1016/j.landusepol.2013.10.020

Patton, M. Q. (2002): Qualitative Research and Evaluation Methods. 3rd Edition. - Sage, London. $663 \mathrm{p}$.

Pellizzoni, L. (2003): 'Uncertainty and Participatory Democracy'. - Environ. Value. 12(2): 195224. http://dx.doi.org/10.3197/096327103129341298

Rauschmayer, F., Berghöfer, A., Omann, I. \& Zikos. D. (2009): Examining processes or/and outcomes? Evaluation concepts in European governance of natural resources. - Environ. Pol. Governance 19: 159-173. http://dx.doi.org/10.1002/eet.506

Reed, M. S. (2008): Stakeholder participation for environmental management: A literature review. Biol. Conserv. 141: 2417-2431. http://dx.doi.org/10.1016/j.biocon.2008.07.014

Reed, M. S., Evely, A. C., Cundill, G., Fazey, I., Laing, A., Newig, J., Parrish, B., Prell, C., Raymond, C. \& Stringer, L. C. (2010): What is Social Learning? - Ecol. Soc. 15: 1. http://www. ecologyandsociety.org/vol15/iss4/resp1/

Rodela, R. \& Udovč, A. (2008): Participation in nature protection: Does it benefit the local community? A Triglav National park case study. - Int. J. Biodiv. Sci. Manage. 4: 209-218. http://dx.doi. org/10.3843/Biodiv.4.4:4

Rowe, G. \& Frewer, L. J. (2000): Public participation methods: a framework for evaluation. - Sci. Tech. Human Value. 25: 3-29. http://dx.doi.org/10.1177/016224390002500101

Švajda, J. (2008): Participatory conservation in a post-communist context: The Tatra National Park and Biosphere Reserve, Slovakia. - Int. J. Biodiv. Sci. Manage. 4: 200-208. http://dx.doi. org/10.3843/Biodiv.4.4:3

Vidékfejlesztési Minisztérium (2013): Útmutató a Natura 2000 fenntartási tervek készítéséhez. - Vidékfejesztési Minsiztérium, Természetmegőrzési Főosztály, Budapest, kézirat, 29 p.

Young, J. C., Jordan, A., Searle, K. R., Butler, A., Chapman, D. S., Simmons, P. \& Watt, A. D. (2013): Does stakeholder involvement really benefit biodiversity conservation? - Biol. Conserv. 158: 359-370. http://dx.doi.org/10.1016/j.biocon.2012.08.018

Hivatkozott jogszabályok:

275/2004. (X. 8.) Korm. rendelet az európai közösségi jelentőségü természetvédelmi rendeltetésű területekröl

43/2012. (V. 3.) VM rendelet az Európai Mezőgazdasági Vidékfejlesztési Alapból a Natura 2000 területek fenntartási terveinek készítéséhez nyújtandó támogatás igénybevételének részletes szabályairól

\section{Függelék}

A cikkhez tartozó online függelék a folyóirat honlapján található.

Függelék 1: A Natura 2000 területek listája, amelyekre fenntartási tervek készültek a vizsgált részvételi folyamatokban 


\title{
Evaluation of participatory processes of Natura 2000 management planning
}

\author{
Eszter Kovács ${ }^{1,2}$, Gabriella Kiss ${ }^{3}$, Eszter Kelemen ${ }^{1,2}$, Veronika \\ Fabók $^{4,2}$, Ágnes Kalóczkai ${ }^{5,4,2}$, Barbara Mihók ${ }^{5,6}$, György Pataki ${ }^{3,2}$, \\ Bálint Balázs ${ }^{1,2}$, Györgyi Bela ${ }^{1,2}$, Boldizsár Megyesi ${ }^{7}$ and Katalin \\ Margóczi ${ }^{8,6}$
}

${ }^{1}$ Szent István University, Institute of Nature Conservation and Landscape Management, H-2100 Gödöllö, Páter Károly u. 1., Hungary

${ }^{2}$ Environmental Social Science Research Group (ESSRG), H-1024 Budapest, Rómer Flóris u. 38., Hungary

${ }^{3}$ Corvinus University of Budapest, H-1093 Budapest, Fövám tér 8., Hungary

${ }^{4}$ Szent István University, Environmental Sciences Doctoral School, H-2100 Gödöllö, Páter Károly u. 1., Hungary

${ }^{5}$ Institute of Ecology and Botany, Centre for Ecological Research, Hungarian Academy of Sciences, 2163 Vácrátót, Alkotmány u. 2-4., Hungary

${ }^{6}$ Akciókutatók a Fenntarthatóságért Egyesület (AKUT), H- 6726 Szeged, Fürj u. 49., Hungary

${ }^{7}$ Institute for Sociology, Centre for Social Sciences, Hungarian Academy of Sciences, H-1014 Budapest, Országház u. 30., Hungary

${ }^{8}$ Department of Ecology, University of Szeged, H-6726 Szeged, Középfasor 52., Hungary e-mail:kovacs.eszter@mkk.szie.hu

The institutionalisation of public participation is still in its infancy in Hungary. Nevertheless, stakeholder involvement in the preparation of Natura 2000 management plans has become widespread. Valuation of these processes can be useful for planners, teams managing participatory processes and conservation decision-makers as well. In this paper 23 participatory planning processes are evaluated based on criteria derived from the international literature on participation and tailored to participatory management planning of Natura 2000 sites. Our analysis shows that the examined processes only partly meet the required criteria and about the conservation outcome of the processes no sufficient information is available. The strength of the examined processes is the skilled and independent participatory team with social science background. Our findings also show that a supporting policy is crucial for the success of management planning and related participatory processes as well.

Keywords: participatory planning, Natura 2000 network, management plans 